\title{
Impact of COVID-19 Lockdown on Agriculture Education in Nepal: An Online survey
}

\author{
Sandesh Thapa ${ }^{1 \star}$, Neha Rai ${ }^{2}$, Janak Adhikari ${ }^{1}$, Anup Ghimire ${ }^{1}$, Anka Kumari Limbu ${ }^{1}$, Arpana Joshi ${ }^{1}$, \\ Sandhya Adhikari ${ }^{3}$
}

\begin{abstract}
${ }^{1}$ Gokuleshwor Agriculture and Animal Science College, Tribhuvan University, NEPAL
${ }^{2}$ G.P. Koirala College of Agriculture and Research Center, Purbanchal University, NEPAL

${ }^{3}$ Paklihawa Campus, Institute of Agriculture and Animal Science, Tribhuvan University, NEPAL

*Corresponding Author: sand.thapa.2056@gmail.com
\end{abstract}

Citation: Thapa, S., Rai, N., Adhikari, J., Ghimire, A., Limbu, A. K., Joshi, A., \& Adhikari, S. (2020). Impact of CoVID-19 Lockdown on Agriculture Education in Nepal: An Online survey. Pedagogical Research, 5(4), em0076. https://doi.org/10.29333/pr/8465

\section{ARTICLE INFO}

Received: 29 May 2020

Accepted: 17 Jul. 2020

\begin{abstract}
The official announcement of COVID-19 as a global pandemic on 11 March 2020 by WHO, the world economy has abruptly declined, billions of people are in lockdown, maintaining self-isolation.

In this survey, 150 respondents were selected randomly and this survey intends to highlight the impact of lockdown in agriculture Students on their education along with their response towards pros and cons. This survey shows that maximum respondent, around $52 \%$ of them found lockdown beneficial in the sense that it has helped to neutralize the gravity of viral infection and $48 \%$ of them doesn't found it beneficial as their educational schedule has been halted. The practical education of a student is disturbed due to lockdown and now they are utilizing this period involving in online courses, training, and webinars.

Many of them couldn't have access to the internet to catch the session, thus the government should initiate policy in education through a long term perspective so that no pandemic could interfere with the educational institution in digital world.
\end{abstract}

Keywords: pandemic, research studies, Tribhuwan University, webinars

\section{INTRODUCTION}

Coronavirus disease (COVID-19) could also be a transmissible or disease caused by severe acute respiratory syndrome coronavirus 2 (SARS-CoV-2). Novel Corona Virus (COVID-19 or 2019-nCoV) is an appearing worldwide health concern that requires a rapid diagnostic test (Lamb et al., 2020). From the time immemorial world has passed through the global pandemic, so the global pandemic is not a new topic for mankind which has abruptly brought significant impacts on public health and the global economy. As per the World Health organization, corona virus consists of considerable family that not only affects birds and animals but also human beings (WHO, 2020). Some of the global pandemic due to the family of these viruses are Severe Acute Respiratory Syndrome (SARS) 2002-2003 and Middle East Respiratory Syndrome (MERS) 2015 (Cascella et al., 2020). Thus, on March 11, 2020, WHO has officially declared outburst of COVID 19 as a global pandemics (Cucinotta \& Vanelli, 2020). This virus has hard hit developed countries of the third world including Italy, Spain, the United States with maximum human loss. Globally all together 3,664,011 cases have been reported (The Guardian, 2020). Out of these the death number reached to 257,301 and 982,592 populations have been recovered from COVID-19 (Data correct at 12.10 UTC 6 May). As per WHO reports, the number of coronaviruses, cases till $5^{\text {th }}$ May 2020 has crossed 80 in Nepal (good part is that no death report has been issued and more than 16 are recovered) (Worldometer, 2020). The pandemic COVID 19 is escalating so rapidly worldwide due to which protection measures cost for humans is inflecting as a result of which has abated the world's economic activities. According to the World Economic Outlay Report (2020), It has been estimated that the global economy is projected to reduce sharply by -3 percent in 2020, which is much more worse than 2008-2009. It has been also assumed that there will be a rise in the global economy by 2021 by 5.6 percent as all the activities will normalize assisted by policy makers. COVID-19 was first spotted and recognized from pneumonia victim patient belongs to Wuhan, China (Zhu et al., 2020).

The report from ADB (2019) shows that before the outbreak of the pandemic disaster the growth percentage has been expected as 7.1 in Nepal due to infrastructural development, post-earthquake construction procedure increased export of electricity, tourist visit, enhanced agriculture production, and remittance. Now all these components for the GDP growth rate will be affected in 2020 due to COVID-19. Similar to that of an economic perspective, COVID-19 has a detrimental effect on the field of education and research studies. Thus, this paper entails about the effect of COVID-19 lockdown in the scenario of agriculture students on their 
study and extension. Specifically, we will discuss about student response towards lockdown and both positive as well as negative impacts on the field of education faced by them.

\section{METHODOLOGY}

A preliminary online survey was conducted in May (2-4), 2020 through which respondents were selected by random sampling techniques. The sampling size was adjusted to 150 students of faculty viz. Agriculture, forestry, veterinary and animal husbandry, and fishery from different institutions across Nepal, however very few respondents were from India and Germany too.

The students were selected from different faculties and forms were circulated through emails and messaging. Out of selected 350 respondents, only 150 filled their form within a stipulated time. The main reason for not getting $100 \%$ of the respondents responding may be due to lack of internet facility, ignorance to form, and unavailable on social media during those days. Research instrument includes questionnaire in google forms, various questions and use of social media like Gmail, Whatsapp, Viber, and Facebook for circulation of information.

The research design was done to meet the respondent's view towards the impact of lockdown on their education and their response towards its pros and cons. Similar type of survey was conducted by (Rossi et al., 2020) and also suggested by (Bidarbakhtnia et al., 2020) for online surveys during these days to excel the research.

Data entry was done using MS excel 2016 and IBM SPSS v.20. Statistical analysis includes descriptive analysis, mean, standard error, and range using SPSS v. 20. Inferential statistics include the chi-square test.

\section{RESULTS AND DISCUSSIONS}

\section{Socio-economic Characteristics}

An online preliminary survey was conducted in which randomly 150 respondents were selected out of which $54.0 \%$ were female and $48.0 \%$ were males. The ethnicity of the respondents; Brahmin (62.0\%) were found to be more than other ethnic groups followed by Chhetri's (27.9\%), Janjatis (10\%), and Dalit $(0.7 \%)$. Survey finding shows that respondent's age was between 17 to 27year old.

The randomly selected 150 respondents belong to different colleges with different faculties \& levels. Among them $80 \%$ were from Tribhuwan university (34\% were from GAASC, $12.7 \%$ were from Lamjung college, 12.7 were from Paklihawa college, $1.3 \%$ from forestry (Hetauda), $0.7 \%$ from IAAS (Chitwan), $4 \%$ from Live science, 3.3\% from Horticulture college (IIlam), $2 \%$ from IAAS (Kathmandu), $9.3 \%$ from prithu college) 8.7\% were from agriculture and Forestry University (6.7\% AFU (Rampur), $1.3 \%$ from AFU (Sindhuli), 0.7\% from AFU (Pokhara), , 0.7\% from valley Krishi campus ), 2.0\% from Banaras Hindu University, and $0.7 \%$ from Leibtniz University, 5.4\% from Purwanchal University (4.7\% from GPCAR, 0.7\% from NPI). Out of 150 respondents, 9.3\% were from first semester, $32.0 \%$ from second semester, $22.0 \%$ from fourth semester, $5.3 \%$ from fifth semester, $16.0 \%$ from sixth semester, $9.3 \%$ from eight-semester, $4 \%$ from master first semester, $0.7 \%$ from master $3^{\text {rd }}$ semester and $1.3 \%$ were pass-out students. Distribution of respondents as per faculty is $94.7 \%$ were from agriculture faculty, $0.7 \%$ from fishery, $1.3 \%$ from forestry, and $3.3 \%$ from veterinary and animal husbandry faculty.

\section{Response of Students Regarding the Lockdown}

Among the surveyed 150 respondents, $52 \%$ of the respondents found lockdown beneficial, but $48 \%$ of the responded as not beneficial. The main reason regarding lockdown being beneficial is it helped to control the widespread of the virus across the country and to date, no deaths have been recorded in Nepal. Also, respondents claimed that they got a chance to get involved in varieties of work at home and explore their knowledge regarding agriculture in their fields and also got a chance to spent a quality time with family members after a long time. However, students who were having their exams found it not beneficial as their timeline of study is interrupted and their semester schedule is disturbed. They are mentally disturbed (Meda et al., 2020) due to lockdown which seems to be unhealthy regarding physical health but staying at home is necessary to prevent spread of disease. The details of respondents' responses regarding finding lockdown beneficial and harmful are shown in Figure $\mathbf{1 a}$ and Figure $\mathbf{1 b}$. In following lockdown, the information and awareness provide by medias and health ministry regarding social distancing was circulated well as a result of which all the respondents are following more strictly. 

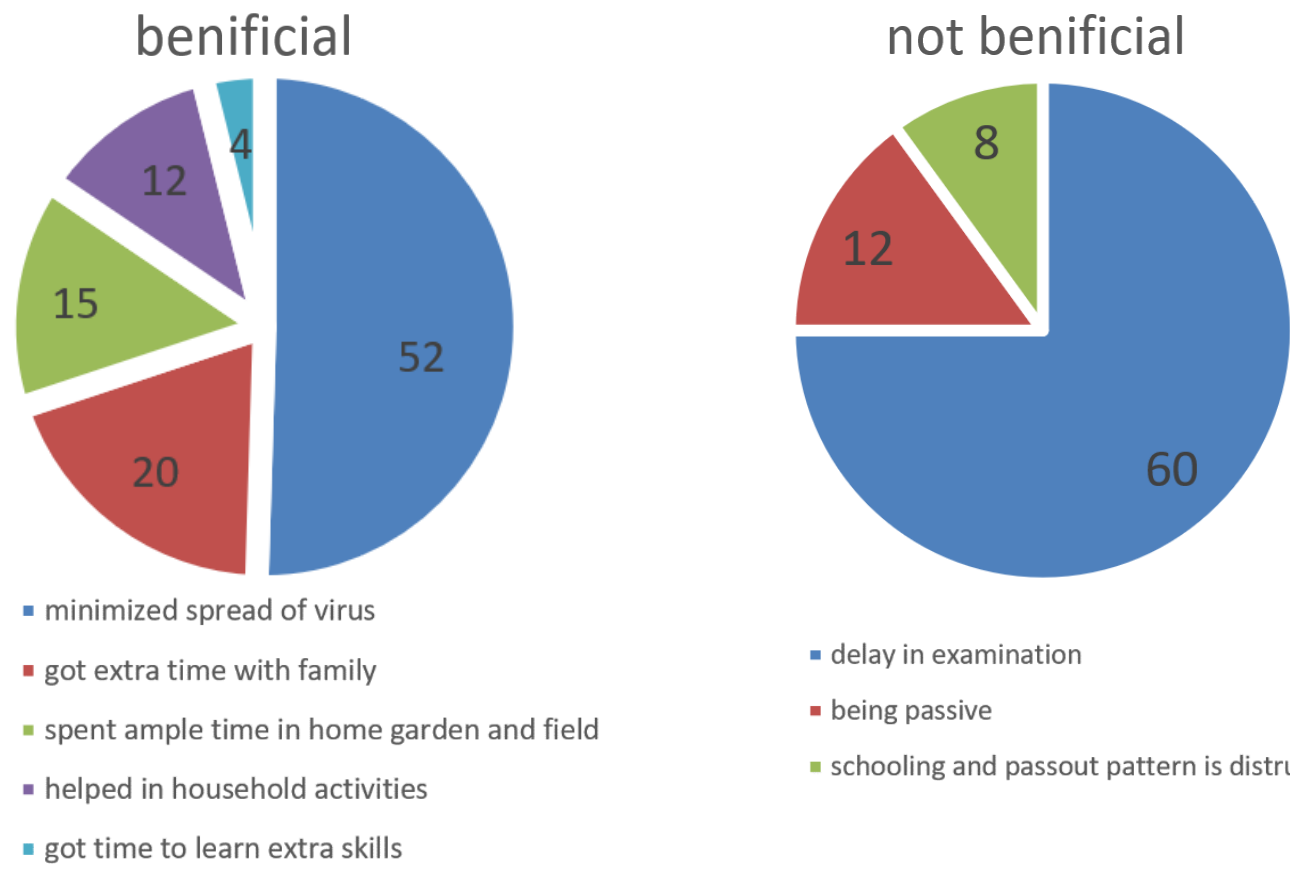

- delay in examination

- being passive

- schooling and passout pattern is distrubed

Figure 1. a) benicifial aspects of lockdown b) not beneficial aspect of lockdown

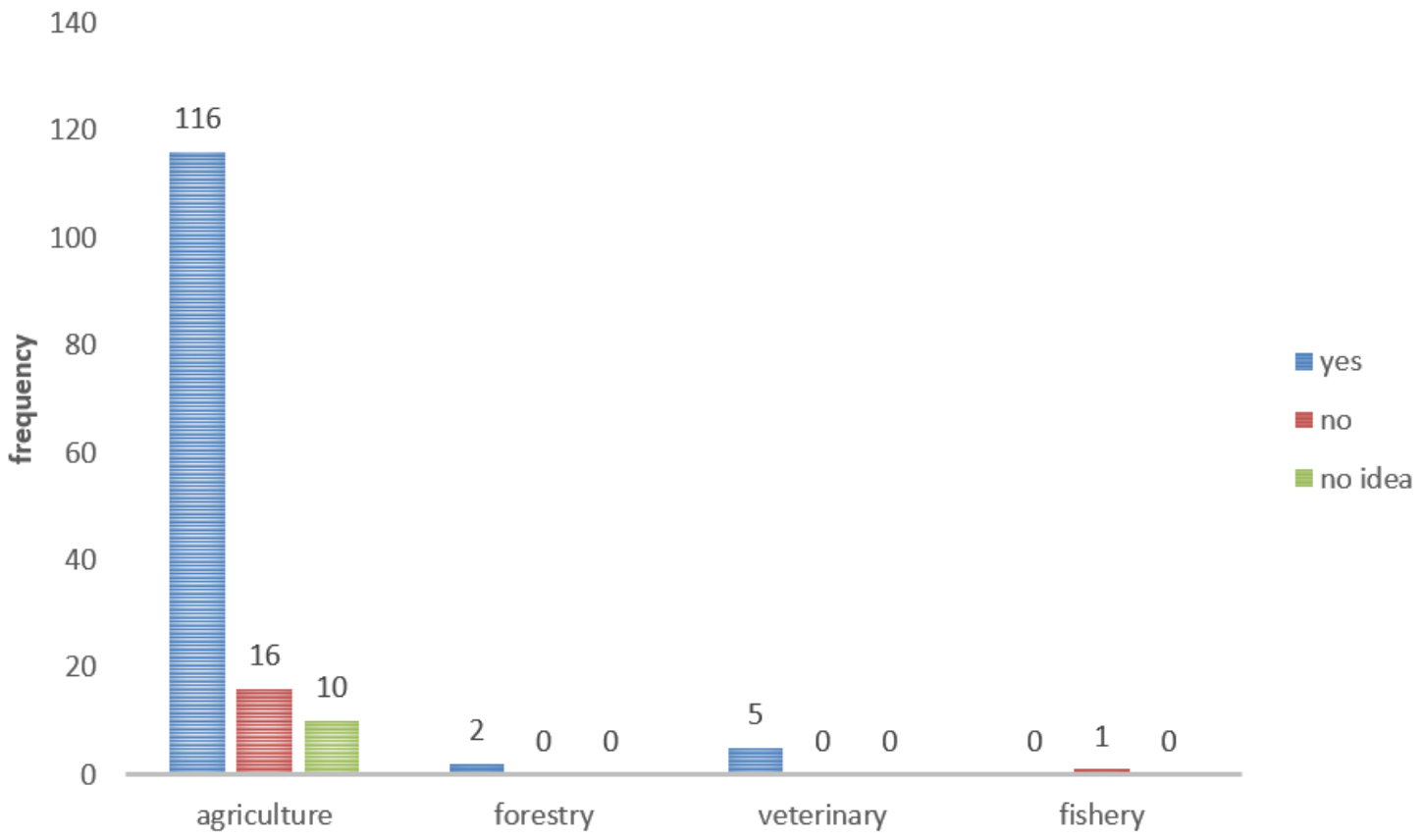

Figure 2. Impact of lockdown on education (respondents response)

\section{Impact on Education}

In this study, most of them had reported having a negative impact on education (82\%) and no idea (6.7\%) and $11.3 \%$ didn't found a negative impact on education respectively (Figure 2). However, much of the respondents claimed that the practical education of students is disturbed (82\%), 5.3\% have no idea about this and $12.7 \%$ of the respondents think that there's no effect on practical due to lockdown.

The main reason for the practical education is due to course requirements due to seasonal arrangement of crops ( $31.3 \%)$, there would be lack of infrastructure after lockdown (17.3\%), there would be less time for practical (38\%) and $13.3 \%$ have no idea about this. Generally, in Nepal, agriculture students are enrolled in the spring semester each year, and thereafter the arrangement of courses is as per season so that it influences practical education. Cereal crop production placed in the second semester (generally falls between Feb-Aug), during this period cultivation of rice, wheat, maize (Manandhar, 2005) is feasible but due to lockdown once the class is interrupted it is hard to achieve that time for practical. Similarly, due to influenza outbreak in 2000 , teachers strike in Israel led to schools closure and almost 85 countries was affected at that time (Cascella et al., 2020). 


\section{students involvement during lockdown}

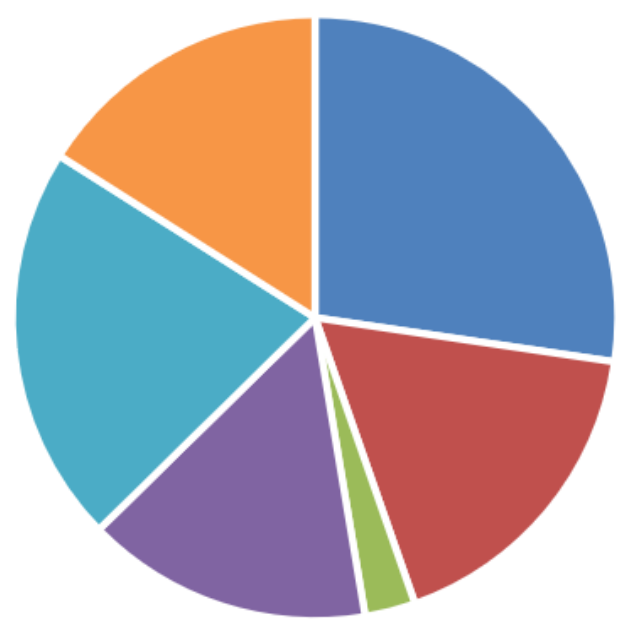
- preparing for exams
- maintaining home garden
- establishing rooftop garden
- research studies
- all of these
n none of them

Figure 3. Students involvement during lockdown

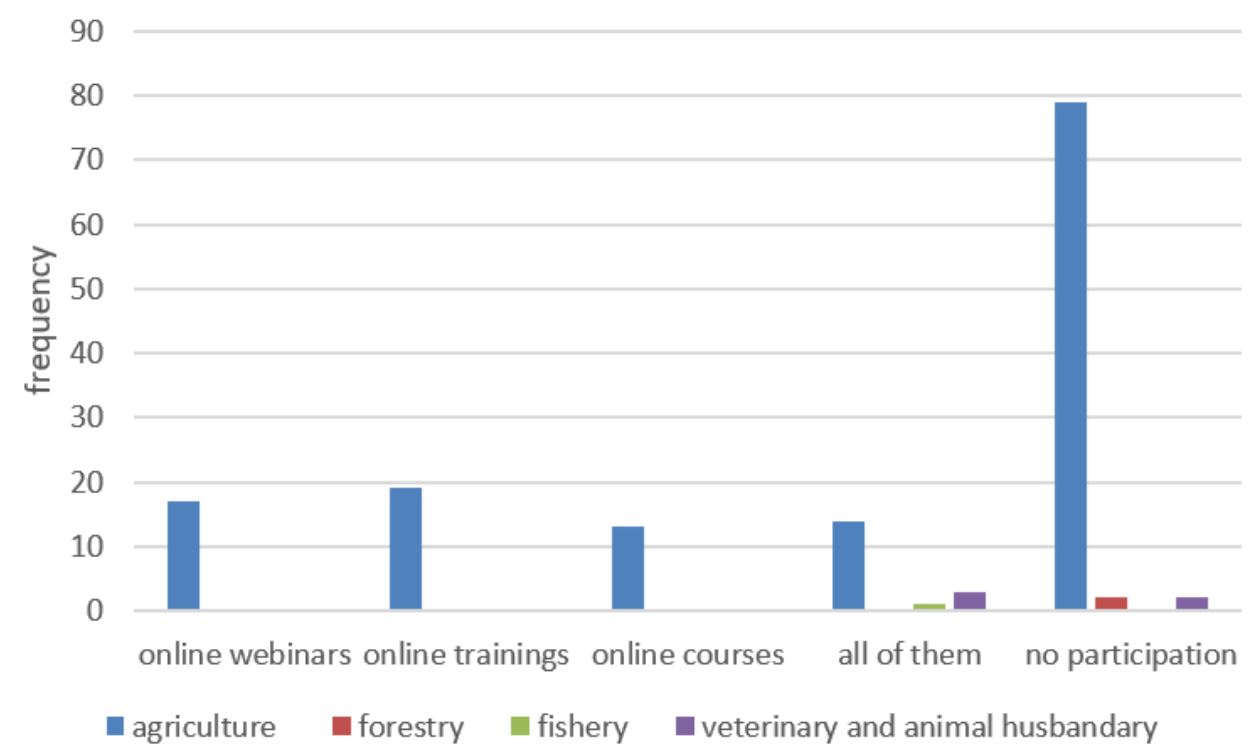

Figure 4. Students involvement on extra work during lockdown

The main reason for the huge impact on education is due to the lack of long term perspective in the field of education (Wan, 2020). Similar, to that of agricultural education medical education is being disturbed due to pandemic and are problematic attending classes (Parvati et al., 2020). The lockdown has huge impact on education of students and their exams which has also been observed by Jadhav (2020). Burgess and Sievertsen (2020) reported that COVID-19 and shut down of educational institutions have a huge effect on graduate students and their research activities. However, must of the nations are resuming their classes by digital means like Zoom and Google meet (Radwan \& Radwan, 2020), yet it is not accessible to all of those residing in developing countries (UNESCO, 2020).

\section{Involvement of Student during a Lockdown}

During these days of lockdown due to COVID-19, all of them are spending their time with their families and sharing ideas and knowledge. At this time student are involved in preparing for exams and the upcoming semester (27.3\%), maintaining home garden (17.3\%), establishing rooftop gardens (2.7\%), doing some research studies (15.3\%) (Figure 3). However, $21.3 \%$ are involved in all of these activities and $16 \%$ are involved in none of them. The response of students on involvement in online courses, training, and webinars was only $44.7 \%$ and the rest $55.3 \%$ do not have access to high-quality internet to participate (details are shown in Figure 4; chi sq. $=21.085$, $p$-value $=0.049$ ). Since major source of information for Nepalese is from radio and national television (Kharel, 2018), so there might be problem on accessing internet and many places of Nepal are still devoid of internet facilities. Though the continuing in classes are being achieved by zoom classes (Anonymous, 2020) but most of the institutions in Nepal are 
facing problem in launching online classes due to unequal access to resources among all of their students (Mustafa, 2020). Similar to present situation past pandemic hold a potential role in disturbing education sectors like the influenza outbreak in France (1957), Israel (2000), Hongkong (2008), America and Australia (2003) (Cascella et al., 2020). Though it has negative impact on education but the only solution for outbreak control and reducting the number of patient visit it seemed to be effective.

\section{CONCLUSION}

The COVID-19 pandemic has affected economic as well as educational systems worldwide, leading to the near-total closures of schools, universities and colleges. Our study managed to capture some views of students regarding about the lockdown and their activities during lockdown along with the impact on education. From our results we claimed that more than half of the respondents find the lockdown beneficial where they are strictly following rules and regulation of lockdown and spending quality time with their family members which was not possible in other regular days. As well as students are involving in indoor activities such as joining online courses, trainings, webinars, maintaining home garden, establishing rooftop gardening and some of the students are preparing for their upcoming exams. There is negative impact on education, mainly for the agricultural students which focuses on practical field work and can't possible in online classes. The corona virus pandemic and the lockdown has brought enormous uncertainty for students studying for exam, hoping to start new semester or college or university and entering the world of work. Therefore, the Government should initiate policy in education through long term prospective so that no any pandemic could interfere the educational institutions in digital world.

\section{ABBREVIATIONS}

IAAS : Institute of Agriculture and Animal Sciences

AFU : Agriculture and Forestry university

GAASC : Gokuleshwor Agriculture and Animal Science college

GPCAR : G.P. Koirala College of Agriculture and Research Center

NPI : Nepal Polytechnic Institute

\section{REFERENCES}

ADB. (2019). Macroeconomic Update: Nepal (April 2019).

Anonymous. (2020). Interim Guidance for Administrators of US K-12 Schools and Child Care Programs to Plan, Prepare, and Respond to Coronavirus Disease 2019 (COVID-19). Retrieved from https://www.cdc.gov/coronavirus/2019-ncov/index.html

Bidarbakhtnia, A., Statistics, E., Reviewers, D., Halderen, G. Van, Division, E. S., Tam, S., \& Division, S. (2020). Surveys Under Lockdown; a pandemic lesson. (23).

Burgess, S., \& Sievertsen, H. H. (2020, April 1). Schools, skills, and learning: The impact of COVID-19 on education. https://voxeu.org/article/impact-covid-19-education

Cascella, M., Rajnik, M., Cuomo, A., Dulebohn, S. C., \& Di Napoli, R. (2020). Features, Evaluation and Treatment Coronavirus (COVID19). In StatPearls. Retrieved from http://www.ncbi.nlm.nih.gov/pubmed/32150360

Cucinotta, D., \& Vanelli, M. (2020). WHO declares COVID-19 a pandemic. Acta Biomedica, 91, $157-160$. https://doi.org/10.23750/abm.v91i1.9397

Gutiérrez, P., \& Clarke, S. (2020). Coronavirus world map: which countries have the most cases and deaths? The Guardian. Retrieved from https://www.theguardian.com/world/2020/jul/25/coronavirus-world-map-which-countries-have-the-most-covid-19cases-and-deaths

IMF. (2020). World Economic Outlook, April 2020: The Great Lockdown. Retrieved on May 7, 2020 from International monetary fund https://www.imf.org/en/Publications/WEO/Issues/2020/04/14/weo-april-2020

Jadhav, V. V. (2020). Role of Social Media during lockdown on various health aspects Role of social media during lockdown on various health aspects. (April).

Kharel, S. (2018). Information and Communication Technology for the Rural Development in Nepal. Tribhuvan University Journal, 32(2), 177-190. https://doi.org/10.3126/tuj.v32i2.24714

Lamb, L. E., Bartolone, S. N., Ward, E., \& Chancellor, M. B. (2020). Rapid Detection of Novel Coronavirus (COVID19) by Reverse Transcription-Loop-Mediated Isothermal Amplification. https://doi.org/10.2139/ssrn.3539654

Manandhar, D, N. (2005). Inventory of Pesticides in Nepal. Report submitted to POPs Enabling Activities Project. Ministry of Environment, Science and Technology, Kathmandu, Nepal, 96.

Meda, N., Pardini, S., \& Novara, C. (2020). COVID-19 and depressive symptoms in students before and during lockdown. (May). https://doi.org/10.1101/2020.04.27.20081695 
Mustafa, N. (2020). Impact of the 2019 - 20 coronavirus pandemic on education. International Journal of Health Preference Research, 1-36.

Parvati, I., Ojcius, D. M., \& Aziz, K. (2020). Impact of COVID-19 on dental education in the United States Impact of COVID-19 on dental education in the United States. J Dent Educ., (April), 1-5. https://doi.org/10.1002/jdd.12163

Radwan, A., \& Radwan, E. (2020). Social and Economic Impact of School Closure during the Outbreak of the COVID-19 Pandemic: A Quick Online Survey in the Gaza Strip. Pedagogical Research, 5(4), em0068. https://doi.org/10.29333/pr/8254

Rossi, R., Socci, V., Talevi, D., Mensi, S., Niolu, C., Pacitti, F., Di Lorenzo, G. (2020). COVID-19 pandemic and lockdown measures impact on mental health among the general population in Italy. An $\mathrm{N}=18147$ web-based survey. MedRxiv, (April), 2020.04.09.20057802. https://doi.org/10.1101/2020.04.09.20057802

UNESCO. (2020). 290 million students out of school due to COVID-19: UNESCO releases first global numbers and mobilizes response. Retrieved from https://en.unesco.org/news/290-million-students-out-school-due-covid-19-unesco-releases-firstglobal-numbers-and-mobilizes

Wan, Y. S. (2020). Education during COVID-19. (April).

WHO. (2020). Situation Report-92 HIGHLIGHTS.

Worldometer. (2020). Coronavirus Cases. Worldometer, pp. 1-22.

Zhu, N., Zhang, D., Wang, W., Li, X., Yang, B., Song, J., \& Tan, W. (2020). A novel coronavirus from patients with pneumonia in China, 2019. New England Journal of Medicine, 382(8), 727-733. https://doi.org/10.1056/NEJMoa2001017 